\title{
The Effect of Teacher Performance, Communication Information Technology, Curriculum 2013 and School Climate on Education Quality in High School Public 1 Woha District, Bima Regency, West Nusa Tenggara
}

\author{
Indra Dewi Sari ${ }^{1}$, Rudy Wahyono ${ }^{2}$ and Fajar Supanto ${ }^{3}$ \\ ${ }^{1}$ Postgraduate Students Master of Management, University of Merdeka Malang, Indonesia \\ ${ }^{2,3}$ Faculty of Economics and Business, University of Merdeka Malang, Indonesia
}

\begin{abstract}
This study aims to describe the analysis of teacher performance variables, information communication technology, curriculum 2013, the school climate affects the education quality. know among the independent variables that have a dominant influence on the variable education quality at SMAN 1 Woha Bima West Nusa Tenggara. This research sample number 78 Teachers. Data were analyzed using descriptive analysis techniques and analysis liner whose results showed the influence of teacher performance, information communication technology, curriculum 2013, the school climate on the education quality, which means if the performance of teachers, information communication technology, curriculum 2013, the school climate is good then the education quality will increase.
\end{abstract}

Keywords: Teacher Performance, Communication Information Technology, Curriculum 2013, School Climate, Education Quality.

\section{INTRODUCTION}

Current era education world was shocked by the industry-based education pengelelolaan namely education agency efforts in improving the quality of their education in a professional manner [1]. The concept consistently focus on the strategy towards continuous improvement to achieve the needs and satisfaction of stakeholders in education. The strategy was developed in Enhancing the education quality that is how the institution should position themselves as services institution, provides services according to what the customer expectations. Because the quality of the base is formed costumer bagamaina statified [1]. If the needs or expectations are changing, however, the organization pendiddikan by itself and even alter the quality of the restoration of production in the education component is the performance of teachers, teaching facilities such as information and communications technology as a medium of learning support, curriculum, school climate also other educational components.

According Maskoran challenges in improving the education quality among the escalation of extra value (added value), which is how to increase the value-added (development and improvement of the education quality) to the institution as a consequence in response to disciplinary knowledge and information communications technology [2]. Speak up challenge in increasing the added value that changes. Changes to improve the education quality is how to improve the performance of teachers, availability of information and communication technology as a medium of learning, curriculum enrichment, provision of facilities, and an atmosphere conducive school environment and supporting learning activities and improve school connections to the success of the education quality itself.

Teacher performance is a capable and competent teachers who are able to adapt to the increasingly sophisticated scientific developments. Qualified and competent teachers should also be able to practice appropriate forms and instructional design time demands and needs of learners. Implementation of this method will create a pleasant learning atmosphere, enjoy teaching and will ultimately produce quality learning activities, especially student achievers. Act - Act No. 14 Year 2005 on Teachers and Lecturers Article 4 confirms that teachers teaching agent serves to improve the quality of national education [3]. To be able to perform its function well, teachers are required to have certain conditions, one of which is a competence that is reflected from its performance.

Communication Information Technology merupkan one means danatau instruments used to transfer data both in acquiring a data / information and provide the information to others and can be used as a tool to communicate both one-way or two-way [4]. The curriculum is said to be good if it fits your needs and desires of learners that includes components of the objectives, content (teaching materials), strategies and evaluation in order to achieve the desired results.. Barbara gives the concept: The curriculum can be said to be a product, as well as program curriculum, Curriculum is a desired result or be achieved, curriculum as a learning experience [5]. A good school is how schools can make learners, teachers or those who are in it feel comfortable while in 
school.School climate or climate work environments in schools are all experienced by students, staff, teachers and school members interacting in the school grounds. Usman, defines school climate or the physical working climate or tangible and intangible are "emotional" [6]. How educators connect together the atmosphere at school or work situations such as safety at work, the atmosphere is pleasant work space, illumination and air circulation are met, adequate facilities and means of learning, social protection are met, position monitoring, promotion and so on.

\section{LITERATURE REVIEW}

Education Qualityrefers to the attainment achieved by a school in a specific time period. Feat achieved or educational attainment (Student Achievement) visits of academic ability test. Achievements in different sectors namely achievements in the field of sports, arts, crafts, danlainnya. Another school attainment also be a disembodied state (not visible) like atmosphere of intimacy, mutual respect, high discipline, level of cleanliness [7].

Teacher performancea demonstrated ability of teachers in the running of their obligations in the task or work. Performance is said to be successful if the results achieved benchmarks set properly [8]

Information and Communication Technology namely infrastructure (hardwere, softwere, usewere) systems and methods to acquire, transmit, process, analyze, store, organize, and utilize the data fruitfully [9]. Curriculum 2013 is seen as a concept designed to organize the learning process under the direction and responsibility of the school or educational institution together with staff teaching [10].

School climate according Sargiovani in Sulistyorini, which stated Pitchart \& Karastek that the school environment is a hallmark of the school that became a characteristic that distinguishes a school with other schools, affecting the attitude patterns principal, faculty, and students even school staff [11]. Psychological terms, a school climate that is all the flavor experienced by all residents of a school.

\subsection{Influence of Teachers Performance, Communication Information Technology, Curriculum 2013 School Climate on Education Quality}

Education Quality refers to the processes and outcomes of education. the point is the education quality in the process with regard to teaching materials, methodologies, facilities, finance, environment, energy, etc.. The education quality at the results, related to the achievement that the school achieved within a certain time period such as "test academic skills through general tests, report cards, national exams similar non-academic abilities through sports, arts skills as well".. School achievement can be shaped state untouchable (intangible), such as the atmosphere of intimacy, discipline, mutual respect of one another, cleanliness, etc [7].

Effort in improving the education quality requires at least three basic components, such as skills educational resources to educators in other words, financial as well as a learning tool; learning activities can be effective; namely the achievement of useful knowledge, skills, attitudes are also a value - value.

The availability of resources, the quality of teaching and learning process keluaraan quality also can be met if the necessary support such as cost, power berprofesional in education is always available in schools [12]. Opinion Sidi, phase cultivate the education quality: Rebuilding the educational curriculum will provide skill and dexterity of the minimal base, growing quality, skill and professionalism of educators as expected, Assessment standard availability of facilities and infrastructure for quality education, implementation strategies improve quality pendidikann skolah grounded, creating a supportive climate or situation in school [13].

Education Quality by Danim can be measured by indicators: quality inputs (input), by appropriate context or not input the human resources impact, (HR), which is the principal, teachers, laboratory, staff, and students [14]. The fulfillment of quality criteria input books, curriculum, facilities, and more. compliance or absence of such educational softwere, rules, organizational structure and job deskription. Quality inputs such expectations vision, motivation, perseverance and ideals. Quality process (process), is the ability to transform the school's resources and multiple types of input conditions to achieve the degree of added value for students. Such as discipline, familiarity, health, and others. Quality output (output) value of education in terms of academic excellence and versatile skills or extracurricular. Output quality is declared if the learning outcomes of the academic and students nonakademic increased. Outcome is considered qualified graduates directly absorbed in the world of work, appropriate wage and also all those admitted to membership of the graduates get satisfaction through the skills of graduates.

Research conducted by Subroto suggests that the performance of teachers has an influence on the education quality in schools [15]. With the establishment of an adequate ability ownership, understanding what the authority and responsibility, and coupled with a strong impetus from within the teacher to make teaching and learning activities, they will be diligent in carrying out the work, hard-working full-inspiring and creative. In this condition will increase student satisfaction in receiving an education which means that it will create a good quality and is expected by the school is the purpose of education.

The results of these studies suggests that the role or the performance of teachers becomes a very important factor in achieving quality education and learning achievement Siwa. Teacher performance and success is the ability of teachers in implementing the learning tasks through indicators of learning plan, implement, assess the results, guide and train, acted upon learning outcomes [16]. 
Haddad \& Jurich suggests that Communication Information Technology has the potential to improve the education quality by increasing motivation, facilitate the mastery of basic skills, help improve the inquiry and exploration, as well as prepare individuals for a world controlled by technology [17]. Communication Information Technology utilized in the study will be an effective learning tool to engage students in the learning process. Video, television and multi-media computer software providing original and challenging information and improve student understanding through images, colors, sounds, and movement, other than that.

The education quality is achieved when an organization implementing a good curriculum. A good curriculum is the curriculum appropriate to the needs of learners. A good curriculum is capable of creating knowledge, skills (soft skills and hard skills) as well as a good attitude to the learners as a provision that they bring in the business world facing the future industry. The realization of the concept of quality education can memalui objectives, content and materials.

The results showed that the school climate has a positive influence on the quality of learning. Good school climate can be a powerful impetus for teachers and students to produce high-quality learning [18]. It can make the school climate as good: The school has a set of ethical values of morality and ethics that are considered important, school principals, teachers, and students show concern and loyalty to the school goals and values, Schools promising environment and atmosphere are fun, exciting, and challenging for teachers and students, existence of a climate of mutual respect and trust between teachers and fellow learners, mutual trust and open communication in schools, discipline, and so forth.

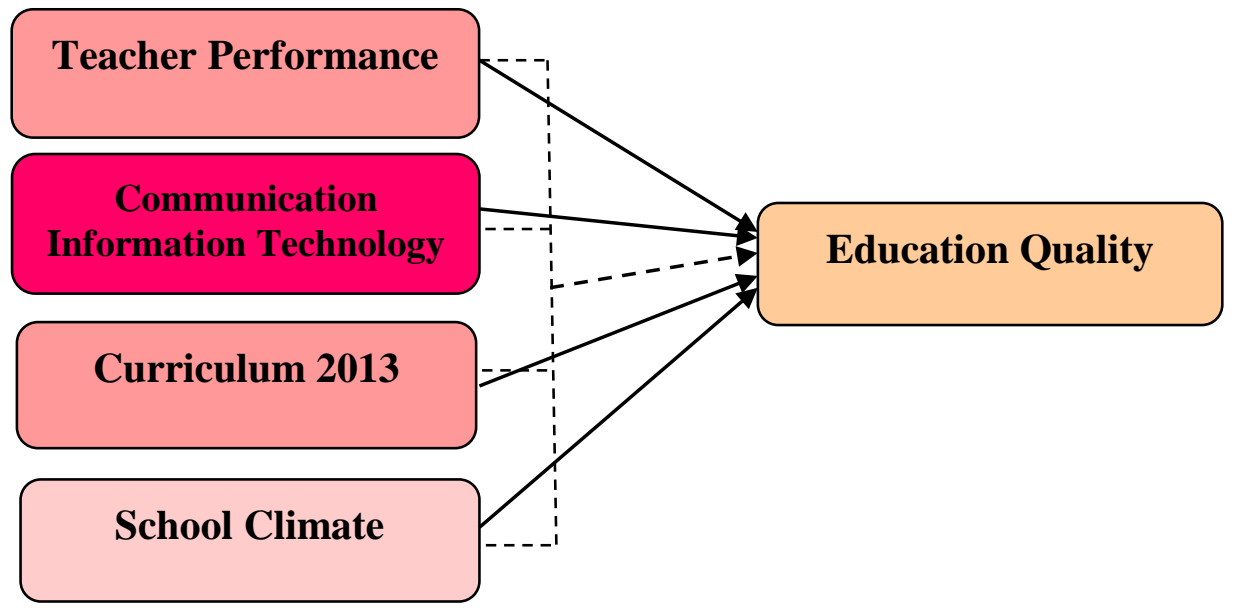

Partial

Simultaneous

Figure 1 Conceptual framework

\subsection{Hypothesis}

$\mathrm{H}_{1}$ : Performance suspected Teacher, Communication Information Technology, Curriculum 2013, School Climate, simultaneously significant effect on Education Quality.

$\mathrm{H}_{2}$ : Performance suspected Teacher, Communication Information Technology, Curriculum 2013, School Climate, partially significant effect on Education Quality.

$\mathrm{H}_{3}$ : Communication Information Technology allegedly dominant influence on the Education Quality.

\section{METHOD}

This research approach is the kind of research explanations. This study seeks to explain the causal relationship that occurs between the variables - the variables and test the allegations that have been formulated [19]. This study describes causal relationships between variables through hypothesis testing and explain the influence of independent variables Teacher Performance, Communication Information Technology, Curriculum 2013 School Climate on Education Quality as dependent variables in SMAN 1 Woha Bima NTB.

\section{DISCUSSION AND RESEARCH}

\subsection{An Overview of Research Subjects}

The author conducted research at State Senior High School 1 Woha District of Bima, West Nusa Tenggara. In this study used as subjects is the overall teacher but samples that researchers use in completing the study are some teachers who have been selected randomly at long and varied in terms of teaching respondents, ie according to the number of samples has been determined as 78 teachers, with details following table. 
Table 1. Characteristics of Respondents

\begin{tabular}{|c|c|c|}
\hline Information & Frequency & Percentage (\%) \\
\hline Gender Respondents & & \\
\hline Woman & 43 & 55 \\
\hline Man & 35 & 45 \\
\hline amount & 78 & 100 \\
\hline Respondents age (Years) & & \\
\hline$<25$ & 3 & 3.85 \\
\hline $25-30$ & 14 & 17.95 \\
\hline $31-35$ & 6 & 7.69 \\
\hline$<35$ & 55 & 70.51 \\
\hline amount & 78 & 100 \\
\hline Teaching long Respondents & & \\
\hline$<5$ & 16 & 20.51 \\
\hline $5-10$ & 18 & 23.08 \\
\hline$<10$ & 44 & 56.41 \\
\hline Amount & 78 & 100 \\
\hline
\end{tabular}

Source: processed data, 2019

\subsection{Validity and Reliability Test Results}

The results obtained by a coefficient of correlation calculation used in mengkur the validity of each item and specify each item pertnyaan proper or improper use. Significance test of correlation coefficient on the value of the significance level of 0.05 , which means an item is considered valid if correlated significantly to the total score. Reliability Test Results is known to show the consistency of the instrument or a gauge or measure the reliability of items or instruments that have been previously tested pertnyaan. Reliability test results obtained by Cronbach alpha values known reliablitas value obtained by each - each variable is more than> 0.6. Then declared a reliable instrument.

\subsection{Descriptive Analysis}

The data have been collected subsequently processed in a table and discussed descriptively. Descriptive size is the provision of good numbers of data daam respondem and in percentage figures shown in the diagram or table. Average - average value of the data has been responded to by the respondent received a positive or good value.

\subsection{Test Assumptions}

\section{a. Multicolinearity}

The purpose of this test were those happen to know a strong relationship between the independent variables. A good regression model is characterized by intercorrelation occur between independent variables. The test results do not happen multikolinieritas symptoms if the tolerance value $>0.10$ and VIF $<10.00$. The test results in the following table.

Table 2. Cooefficients ${ }^{\mathrm{a}}$

\begin{tabular}{|c|c|c|c|}
\hline & \multirow[b]{2}{*}{ Model } & \multicolumn{2}{|c|}{ Colliinearity Statiistics } \\
\hline & & Tolerance & VIF \\
\hline \multirow[t]{4}{*}{1} & Teacher Performance (X1) & 0.227 & 4.408 \\
\hline & Communication Information Technology (X2) & 0.309 & 3.235 \\
\hline & Curriculum (X3) & 0.477 & 2.098 \\
\hline & School climate (X4) & 0.241 & 4.149 \\
\hline
\end{tabular}

a. Dependent Variable: Qedu

Based on the test results showed that the value of tolerance for each - each independent variable $>0.10$ and VIF $<10.00$, it was concluded that the data are free from symptoms Multicolinearity.

\section{b. Autocorrelation}

This test aims to test whether the linear regression model there is a correlation between bullies error at a certain period $(t)$ With the prior period error (tL). The data is said to be no signs of autocorrelation if durbin watson value lies between dU to (4$\mathrm{dU})$. The test results as follows. 
Table 3. Model Summary

\begin{tabular}{|l|l|l|l|l|l|}
\hline Model & $\mathrm{R}$ & R Square & $\begin{array}{l}\text { Adjusted } \\
\text { Square }\end{array}$ & $\begin{array}{l}\text { Rtd. Error of the } \\
\text { Estimate }\end{array}$ & Durbin-Watson \\
\hline 1 & $.900 \mathrm{a}$ & .810 & .800 & 1,767 & 1,790 \\
\hline
\end{tabular}

a. Predictors: (Constant), X4, X3, X2., X1,

b. Dependent variables to: $\mathrm{Y}$

Guide decision-making: $\mathrm{dw}<\mathrm{dL}$ or $\mathrm{dw}>4-\mathrm{dL}$, meaning that there is autocorrelation. $\mathrm{dU}<\mathrm{dw}<4-\mathrm{dU}$, meaning that there is no autocorrelation. $\mathrm{dL}<\mathrm{dw}<\mathrm{dU}$ or $4-\mathrm{dU}<\mathrm{dw}<4-\mathrm{dL}$, meaning there is no conclusion.

Based on the results of autocorrelation test durbin watson compared with the value of the 5\% significance table with a number of research samples 78 Master and 4 independent variables, then $(K=4), N=78$. In the table Durbin Watson value dU $=1.7415<\mathrm{dw}=1.790<4-\mathrm{dU}=2.2585$. Due to the value of durbin watson $(\mathrm{dw})$ lies between the value of dU up to $4-\mathrm{dU}$, then as to which decision-making in autocorrelation can be concluded that there are no symptoms of autocorrelation.

\section{c. Heteroskedastisity (Test Glejser)}

This test aims to determine whether there is or not in common variant of the residual value for all of the observations in the regression model.

Table 4. Coefficients ${ }^{\mathrm{a}}$

\begin{tabular}{|c|c|c|c|c|c|}
\hline \multirow[b]{2}{*}{ Model } & \multicolumn{2}{|c|}{$\begin{array}{l}\text { Unstandartdized } \\
\text { Cooefficients }\end{array}$} & \multirow{2}{*}{$\begin{array}{c}\begin{array}{c}\text { standardized } \\
\text { Coefficients }\end{array} \\
\text { beta }\end{array}$} & \multirow[b]{2}{*}{$\mathrm{t}$} & \multirow[b]{2}{*}{ Sig } \\
\hline & $\mathrm{B}$ & Std. Error & & & \\
\hline 1. (Constant) & 0.998 & 1.622 & & 0.616 & 0.540 \\
\hline Teacher Performance (X1) & 0.082 & 0.060 & 0.324 & 1.356 & 0.179 \\
\hline Communication Information Technology (X2) & -0.002 & 0.070 & -0.006 & -0.029 & 0.977 \\
\hline Curriculum (X3) & -0.072 & 0.040 & -0.301 & -1.821 & 0.073 \\
\hline School climate (X4) & -0.010 & 0.053 & -0.046 & -0.196 & 0.845 \\
\hline
\end{tabular}

a. Dependent Variable: Abs_Res

Based on testing heterokedastisity glejser test results obtained through the significance of teacher performance of each independent variable (X1) 0.179> 0.05 (level of significance), Communication Information Technology (X2) 0.977> 0.05. Curriculum 2013 (X3) 0.073>0.05 and School Climate (X4) 0.845>0.05. So it can be concluded that the data did not occur heterokedastisitas problem.

d. Normality test

This test aims to determine the residual value of a normal distribution of data or not. This test uses kolomogrov Smirnov normality test with the following results.

Table 5. Normality Test Results

\begin{tabular}{|cl|c|}
\hline & & Residual unstandardized \\
\hline $\mathrm{N}$ & & 78 \\
normal Parametersa & Mean & .0000000 \\
& Std. deviation & 1.72062599 \\
Most Extreme Differences & Absolute & .061 \\
& positive & .061 \\
& negative & -.053 \\
Kolmogorov-Smirnov & $\mathrm{Z}$ & .535 \\
Asymp. Sig. (2-tailed) & & .937 \\
\hline
\end{tabular}

a. Test distribution is Normal.

Basis for a decision: If the significance value $>0.05$, then the residual value of normal distribution. If the significance value $<0.05$, then the residual value is not normal. Based on the results of the normality test result is greater than the level 0.9370 .05 significance so that it can be concluded that the residual value of normal distribution. 
International Journal of Advances in Scientific Research and Engineering (ijasre), Vol 5 (11), November-2019

\subsection{Linear Regression Analysis}

This analysis aimed to determine the effect of two or more independent variables $(\mathrm{X})$ on the dependent variable (Y). Multiple linear regression model can be called a good model when it has the accuracy of the estimate and consistent preformance or unbiased and free from classical assumptions. The results of data processing using SPSS 16.00 for windows as follows.

Table 6. Summary of Analysis Results

\begin{tabular}{|c|c|c|c|c|}
\hline Variables & Coefficient Regression & $\mathrm{t}$ & Sig. & Information \\
\hline Teacher Performance $(\mathrm{X} 1)$ & 0.250 & 2,549 & 0.013 & Significant \\
\hline Communication Information Technology (X2) & 0.320 & 2.786 & 0.007 & Significant \\
\hline Curriculum (X3) & 0.160 & 2.468 & 0.016 & Significant \\
\hline School climate (X4) & 0.254 & 2.917 & 0.005 & Significant \\
\hline Constants & 1.477 & & & \\
\hline $\mathrm{R}$ & 0.900 & & & \\
\hline Ajusted R Square & 0.810 & & & \\
\hline F count & 77.873 & & & \\
\hline sig. F & 0.000 & & & \\
\hline $\mathrm{N}$ & 78 & & & \\
\hline \multicolumn{5}{|l|}{ F table $=2.50$} \\
\hline \multicolumn{5}{|l|}{$\mathrm{t}$ table $=1.9930$} \\
\hline Variable Bound = Education Quality & & & & \\
\hline
\end{tabular}

Recapitulation of linear regression analysis are translated into the regression equation form below:

$$
\begin{aligned}
& \mathrm{Y}=\mathrm{a}+\beta 1 \mathrm{x} 1+\beta 2 \times 2+\beta 3 \times 3+\beta 4 \mathrm{X} 4 \text { then, } \\
& \mathrm{Y}=1.477+0,250 \mathrm{X} 1+0,320 \mathrm{X} 2+0,160 \mathrm{X} 3+0,254 \mathrm{X} 4
\end{aligned}
$$

Constants $(\mathrm{a})=1.477$ when the independent variables explain teacher performance, Communication Information Technology, Curriculum and School Climate zero then the dependent variable in education quality is worth 1,477.

$\beta_{1}=0.250$ which is the value of the regression coefficient, shows the independent variables Teacher Performance (X1) is positive which means that if a good teacher performance, it can increase the Education Quality. otherwise if teacher performance is not good then it can degrade in education quality.

$\beta_{2}=0.320$ which is the value of the regression coefficient which shows independent variables Communication Information Technology (X2) is positive pales Communication Information Technology is better, it can improve the education quality. so anyway if Communication Information Technology is not good then it will decline in education quality.

$\beta_{3}=0.160$ is the independent variable regression coefficient Curriculum 2013 (X3) has a positive value indicates that the better the Curriculum 2013 Education Quality increases. And so things denngan otherwise.

$\beta_{4}=0.254$ which is the value of the independent variable regression coefficient School Climate (X4). The regression coefficient has a positive value indicates that the school climate is getting baiik makka cause education quaility be increased. Conversely, if declining, School Climate Education Quality decreasing.

Based on the results of a linear regression on the table recapitulation multiple analisisa regresii linieer then have the figures obtained kooefisien determination (Adjusted R Square), which is 0.810 . This value means that the teacher performance variable (X1), Communication Information Technology (X2), curriculum (X3) and School Climate (X4) simultaneously give effect to the variable Education Quality (Y) by $81 \%$. So the value of $19 \%$ is the influence of other variables or other factors not examined in this study.

\subsection{Hypothesis 1}

Hpotesis 1 is based on if sig. $<0.05$ means that the independent variable (X) simultaneously influence the dependent variable (Y) at analysis results following table.

\begin{tabular}{|c|c|c|c|c|c|c|}
\hline & Model & $\begin{array}{l}\text { Sum of } \\
\text { Squares }\end{array}$ & Df & Mean, Square & $\mathrm{F}$ & Sig. \\
\hline \multirow[t]{3}{*}{ I } & Regresssion & 972717 & 4 & 243179 & 77873 & $.000 \mathrm{a}$ \\
\hline & residual & 227963 & 73 & 3,123 & & \\
\hline & Total & 1200.679 & 77 & & & \\
\hline
\end{tabular}

Table 7. ANOVA ${ }^{b}$

a. Predictors: (Constant), school climate-X4, curriculum_X3, Communication

Information Technology_X2, Teacher Performance_X1 
Table 7. ANOVA ${ }^{b}$

\begin{tabular}{|l|c|c|c|c|c|}
\hline & $\begin{array}{c}\text { Sum of } \\
\text { Squares }\end{array}$ & Df & Mean, Square & F & Sig. \\
\hline I $\quad$ Regresssion & 972717 & 4 & 243179 & 77873 & $.000 \mathrm{a}$ \\
& 227963 & 73 & 3,123 & & \\
residual & 1200.679 & 77 & & & \\
Total & & & & \\
\hline
\end{tabular}

b. Dependent Variable: Education Quality_Y

Based on the table above can be spelled out that $\mathrm{F}_{\text {count }}$ amount of 77.873 with a significance level of 0.000 and $\mathrm{df} \mathrm{df}$ numerator and denominator 4 sebesar73. In testing the first hypothesis, independent variables bahwaa Teacher Performance, Communication Information Technology, Kurukulum and School Climate simultaneously affect the Education Quality.

Comparison between Fcount and Ftabel of the real level $=0.05$. Then Fcount is more besardari 77.873 Ftable total value of 2.50 which means that the variable Teacher Performance, Communication Information Technology, Kurukulum and School Climate simultaneously significant effect on Education Quality in the real degree $=0.05$. In addition to ensuring the significance of independent variables together - equal to the dependent variable by comparing the probability value sig. 0,000 with level $=$ 0.05 , where if a probability value <there are independent variables simultaneously - significant effect on the dependent variable.

\subsection{Hypothesis 2}

This test aims to test the influence of each - each independent variable (X) on the dependent variable (Y).

Table 9. Coefficients ${ }^{\mathrm{a}}$

\begin{tabular}{|c|c|c|c|c|c|}
\hline \multirow[b]{2}{*}{ Model } & \multicolumn{2}{|c|}{$\begin{array}{l}\text { Unstandartdized } \\
\text { Coefficientts }\end{array}$} & \multirow{2}{*}{$\begin{array}{c}\begin{array}{c}\text { standardized } \\
\text { Coefficients }\end{array} \\
\text { beta }\end{array}$} & \multirow[b]{2}{*}{$\mathrm{T}$} & \multirow[b]{2}{*}{ Sig. } \\
\hline & $\mathrm{B}$ & Std Error & & & \\
\hline I. (Constant) & 1,477 & 2,646 & & .558 & .578 \\
\hline Teacher Performance (X1) & .250 & .098 & .273 & 2,549 & .013 \\
\hline Communication Information Technology (X2) & .320 & .115 & .256 & 2,786 & .007 \\
\hline Curriculum (X3) & .160 & .065 & .182 & 2,468 & .016 \\
\hline School Climate (X4) & .254 & .087 & .303 & 2,917 & .005 \\
\hline
\end{tabular}

a, Dependent Variable: Education Quality (Y)

Basis for a decision: if the significance value of $<0.05$ or $t>t$ table means that there is the effect of partially free variable $(\mathrm{X})$ on the dependent variable $(\mathrm{Y})$. If the significance value $>0.05$ or $\mathrm{t}<\mathrm{t}$ table means that there are no partial effect of independent variables $(\mathrm{X})$ on the dependent variable $(\mathrm{Y})$, and or $\mathrm{t}>$ ttable then partially influence variable $\mathrm{X}$ to variable $\mathrm{Y}$. $\mathrm{t}<\mathrm{t}$ table then partially variable $\mathrm{X}$ does not affect the variable $\mathrm{Y}$.

Then the table $=($ nk-1 $)=(0.05 / 2 ; 78-4-1)=(0.025 ; 73)=1.9930$. That is, the Teacher Performance Variables $(\mathrm{X} 1)$, linear regression analysis of test results obtained figures of significance $0.013<$ <f $=0.05$ and 2.549 or $t>t$ table 1.9930 . It was concluded that teacher performance variable partially significant effect on Education Quality. Tekonologi Variable Information Communication (X2), the test results obtained by linear regression analysis of significant value $0.007<$ of $=0.05$ or $2.786 \mathrm{t}$ count $>$ t table 1.9930. It was concluded that the Communication Information Technology variable partially significant effect on Education Quality. Curriculum variable (X3), the test results obtained by linear regression analysis of significant value $0,016<$ of $=0.05$ or $2.468 \mathrm{t}$ count $>\mathrm{t}$ table 1.9930. Then the variable partial Curriculum significant effect on Education Quality. School Climate Variables (X4), the test results obtained by linear regression analysis of significant value $0.005<$ of $=0.05$ and $\mathrm{t}$ or $2,917>\mathrm{t}$ table 1.9930. Then the School Climate variable partially significant effect on Education Quality in SMAN 1 Woha Bima. $\alpha / 2 \alpha \alpha \alpha \alpha$

\subsection{Hypothesis 3}

By looking at the value of regression coefficient in table test Hypothesis 2, which has the largest coefficient value is informai Communication Technology that is equal to 0.320. Then the communication information technology (X2) have a dominant influence on the Education Quality in SMAN 1 Woha Bima. 


\subsection{Implication}

The results of this study seeks to maximize the education quality by taking into account variables - variables that influence it, namely Teacher Performance, Communication Information Technology, Curriculum 2013 and the Climate School.

1) Theoretical implications

a. To improve the education quality that the important thing to note is how to keep the school climate, site of the organization's activities. School climate is a condition that complete not only seen on the physical condition of the school but persaan how creating a safe, comfortable and positive.

b. Communication Information Technology becomes very supportive in improving the education quality. the better utilization of information technology to support learning activities terumata the more skilled teachers as quality indicators and student input.

c. The performance of teachers who are part of the terms of the quality of the input is a barometer of success delivering learning into school goals. So if the teacher's performance is good then the education quality is also increasing

d. A good curriculum is the curriculum that can address the challenges of the present time so as to improve output quality, especially school students as the main output. The success of the curriculum is when students can be successfully utilized in both the world of work or education.

2) Practical implications

The results of this study are used as input for the entire card at the school in improving the education quality meraka connection with the current era challenges that required independent schools in creating school quality to be more empowered.

\section{CONCLUSION}

1) The results of the questionnaire distribution menggambarakan study with questionnaires on teacher performance, information technology Communication, Curriculum 2013 and the Education Quality School Climate overall mean value mendapatakan good or positive.

2) That teacher performance, information technology Communication, Curriculum 2013 and the School Climate simultaneously significant effect on Education Quality in SMAN 1 Woha Bima has been proven and tested statistically.

3) That teacher performance, information technology Communication, Curriculum 2013 and the School Climate partially significant effect on Education Quality in SMAN 1 Woha Bima has been proven and tested statistically.

4) Communication Information Technology scored kooefisien dominant determination as much as 0.320. This means that Communication Information Technology domiman effect on Education Quality in SMAN 1 Woha Bima.

5) Contributions variable based ajusted $R$ Square $\left(R^{2}\right)$ of 0.810. It shows that teacher performance, information technology Communication, Curriculum 2013 and the School Climate can well describe the Education Quality in SMAN 1 Woha Bima by $81 \%$. While $19 \%$ is a variable that is not research such as school leadership and motivation.

\section{SUGGESTION}

1) To further improve the performance of teachers important things that can be done by the school is implementing education and training seminars or how teachers can provide innovative active learning and creative environment menyenagkan (PAILKEM) for the implementation of effective teaching appropriate lessons mengahasilkan school goals.

2) Schools can hold extra subjects every month which is love nationalities in cooperation with the Army KORAMIL to offer courses and disciplinary national vision.

3) For the government because the new 2013 curriculum is applied to the SMAN 1 Woha three years is expected to melaksnakan outreach programs through courses and training curriculum implementation in 2013 in order to achieve a better destination.

4) Mengaharapakan writer for teachers to keep enriching and learning materials with fixed harness Communication Information Technology in facing the demands of today's technology in order to remain a sensitive teacher changes.

\section{REFERENCES}

1. Sallis, Edward, 2008, TQM In Edecation, IRCiSoD, Yogyakarta.

2. Maskoran, Prim Mutohar, 2013, Manajemen Mutu Sekolah, Ar-Ruzz Media, Yogyakarta.

3. UU RI Nomor 14 Tahun 2005 tentang Guru dan Dosen, Sekretariat Negara.

4. Susanto, 2005, Konsep Dasar Teknologi Informasi dan Komunikasi. Diunduh http://nustaffsite.gunadarma.ac.id pada 28 Mei 2019.

5. Barbara, Kozier, 2008, Fundamental of Nursing, Seventh Edition, Vol.2, Jakarta EGC. Diunduh 2018

6. Usman, Husaini. 2009. Manajemen, Teori, Praktek dan Riset Pendidikan. Bumi Aksara. Jakarta.

7. Sowiyah, 2010, Pengembangan Kompetensi Guru SD, Lembaga Penelitian Universitas Lampung, Bandar Lampung

8. Rahmawati, Daryanto, 2013, Penilaian Kinerja Profesi Guru dan Angka Kreditnya, Gava Media. 
9. Warsita, Bambang, 2008, Teknologi Pembelajaran, Landasan dan Aplikasinya, Rineka Cipta, Jakarta.

10. Sukmadinata, Nana Syaodih, 2005, Pengembangan Kurikulum: Teori dan Pratek, Remaja Rosdakarya, Bandung,

11. Sulistyorini, 2000. Manajemen Pendidikan Islam: Konsep, Strategi, dan Aplikasi, Yogyakarta: Teras.

12. Fattah, Nanang. 2008. Landasan Manajemen Pendidikan, Bandung: Remaja Rosdakarya.

13. Sidi, Indra Jati. 2001. Menuju Masyarakat Belajar (Menggagas Paradigma baru Pendidikan). Jakarta: PT. Logos Wacana Ilmu.

14. Danim, Sudarwan, 2007, Visi Baru Manajemen Sekolah, Bumi Aksara, Jakarta.

15. Suryobroto, 2010, Manajemen pendidikan di Sekolah, Ar Ruzzmedia, Yogyakarta.

16. Permendiknas No 41 Tahun 2007 tentang Standar Proses Untuk Satuan Pendidikan Dasar dan Menengah

17. Haddad, W.D. \& Jurich, S, 2002, ICT for Education: Potential dan Potency, Diunduh 2019.

18. Supardi.. 2013. Kinerja Guru. Jakarta: Rajawali Pers.

19. Singarimbun, Masri, Efendi, Sofian, 2005, Metode Penelitian Survei, Edisi Revisi, LP3ES, Jakarta. 